\title{
7188 SAYILI KANUN SONRASI UZLAŞTIRMA KURUMU ÜZERİNE DEĞERLENDİRMELER
}

\section{Dr. Öğr. Üyesi Hüseyin ERTUĞRUL•}

\section{ÖZET}

Türk ceza hukuku sistemimizde izlenen suç ve ceza siyaseti gereği, ceza uyuşmazlıklarını çözümleyecek alternatif çözümlere önem verilmektedir. $\mathrm{Bu}$ alternatif çözümlerin başında, bir ceza muhakemesi enstrümanı olan 'uzlaştırma' kurumu gelmektedir. Bu kurumla, taraflar arasında sağlanan sulh marifetiyle mağdurun zararı telafi edilmekte, ceza muhakemesi süresi kısaltılıp adliyelerin yükü hafifletilmekte ve topluma ekonomik-sosyal faydalar kazandırılmaktadır. 1 Haziran 2005 tarihinde hukuk sistemimize giren bu müessese, dört farklı kanunla değişikliğe uğrayarak uygulama alanı genişletilmiş ve günümüze gelinmiştir. Bu alanda en son değişiklik, 23.10.2019 tarihinde yürürlüğe giren ve ceza mevzuatımızda önemli değişiklikler getiren 7188 sayılı Kanun olmuştur. Bu Kanunla uzlaştırma kurumunda üç farklı düzenleme yapılmıştır. Bunlar, uzlaştırma kapsamındaki suçların genişletilmesi, uzlaştırma işlemleri için öngörülen sürenin artırılması ve uzlaştırma kapsamına giren bir suçun bu kapsama girmeyen başka bir suçla işlenmesi halinde mağdurun aynı olması durumunda uzlaştırmanın yapılamayacağının açıkça ifade edilmesidir. $\mathrm{Bu}$ değişikliklerle öğretideki mevcut eleştirilerin dikkate alındığı söylenebilmekle birlikte, hala teori ve uygulamayı etkileyecek önemli hususlar sırasını beklemektedir. Bu hususların da kanun koyucu tarafından dikkate alınması, uzlaştırma müessesesinin daha verimli ve etkin bir şekilde uygulanması bakımından önem arz etmektedir.

Anahtar Kelimeler: Onarıcı Adalet, Suç, Ceza, Uzlaştırma, Muhakeme.

- Ahi Evran Üniversitesi İ̈BF Siyaset Bilimi ve Kamu Yönetimi, hertugrul83@ahievran.edu.tr ORCID-ID: 0000-0003-1372-2451, (Geliş Tarihi: 06.02.2020 - Kabul Tarihi: 27.04.2020). 


\title{
ANNOUNCEMENT AFTER THE 7188 LAW \\ ON THE EVALUATION OF CONCILIATION AGENCY
}

\begin{abstract}
ABSRACT
In accordance with the criminal and criminal policies pursued in our Turkish criminal law system, alternative solutions that will resolve criminal disputes are given importance. One of these alternative solutions is the 'conciliation' institution which is a criminal procedure instrument. With this institution, the harm of the victim is compensated by the settlement provided by the parties, the duration of the criminal procedure is reduced and the burden of the courthouses is reduced and economic and social benefits are provided to the society. This institution, which entered our legal system on June 1, 2005, was amended with four different laws and its field of application was expanded and reached to the present day. The most recent amendment in this field was the Law no. 7188, which entered into force on 23.10.2019 and introduced significant changes in our penal legislation. With this Law, three different arrangements have been made in the conciliation institution. These are the extension of the crimes within the scope of conciliation, increasing the time for conciliation, and making it clear that conciliation cannot be made if the victim is the same if a crime within the scope of conciliation is committed to another offense. While it can be said that these criticisms have taken into account the existing criticisms of the doctrine, it still awaits the order of important issues that will affect the theory and practice. The fact that these issues are taken into consideration by the legislator is important in terms of more efficient and effective implementation of the conciliation system.
\end{abstract}

Keywords: Restorative Justice, Crime, Punishment, Conciliation, Reasoning. 


\section{GíRIŞ}

Tipe uygun, hukuka aykırı, kusurlu insan davranışları ${ }^{1}$ olarak tanımlayabileceğimiz suçların işlenmesiyle hukuk düzeninin sağlamış olduğu denge bozulmaktadır ${ }^{2}$. Bu dengenin yeniden tesisi amaciyla, teknik anlamda ceza ve güvenlik tedbiri olmak üzere ceza hukuku yaptırımlarına başvurulmakta, bu şekilde ceza adaleti sağlanmaya çalışılmaktadır. Klasik ceza hukuku anlayışı, cezanın birincil anlayışının faile ızdırap çektirilmesi, acı çektirilmesi esasına dayanırken; günümüz ceza hukuku anlayışı ise, cezanın birincil amacının failin işlediği suçtan dolayı içinde bulunduğu kusurluluk durumundan ibrasını esas almaktadır ${ }^{3}$.

Esasen devletlerin ceza adaleti anlayışını, kendi içerisinde üçe ayırmak mümkündür: "Faile haddini bildirme yaklaşımı", "faili ıslah etme yaklaşımı" ve günümüzde en çok etkinlik kazanan "mağdur odaklı yaklaşım" (onarıcı adalet)'dir'.

Faile haddini bildirme yaklaşımı, klasik ceza hukuku anlayışının bir ürünü olup tüm suçlarda asıl mağdur devlettir, failin cezalandırılması devlet menfaati gereğidir düşüncesiyle ortaya çımıştır ${ }^{5}$ Bu anlayışta, devlet fail nezdinde topluma gözdağ Aslında devletin "öç alma", "intikam alma" gibi düşüncelerle hareket etmesi, toplumda bireylerin birbirlerine hoşgörü ve affetme düşüncesi yerine öfkeyle hareket etme, birbirlerine zarar verime eğilimini artırmakta olduğundan günümüz ceza hukuku sistemlerinde tercih edilmemektedir ${ }^{6}$.

1 Öztürk, Bahri/Erdem, Mustafa Ruhan (2013) Uygulamalı Ceza Hukuku ve Güvenlik Tedbirleri Hukuku, 13. Baskı, Ankara, Seçkin Yayıncılık, s.25.

2 Özgenç, İzzet (2019) Türk Ceza Hukuku Genel Hükümler, 11. Bası, Ankara, Seçkin Yayıncilık, s.31.

3 Soyaslan, Doğan (2018) Ceza Hukuku Genel Hükümler, 8. Baskı, Ankara, Yetkin Yayınları, s. 48 vd.; Özgenç, s.31.

4 Bıçak, Vahit (2018) 'Onarıcı Adalet Yaklaşımıyla Ceza Adalet Sisteminin Yeniden İnşası', Adalet Şurası, Ankara, s.1 (https://www.bicakhukuk.com/wpcontent/uploads/2018/01/Vahit-B\%C4\%B1\%C3\%A7ak-2018-Adalet\%C5\%9Euras\%C4\%B1-Tebli\%C4\%9F.pdf, s.e.t:29.10.2019).

5 Özgenç, s.32.

6 Bıçak, s.2. 
Faili sslah etme anlayışında ise, işlenen suç karşılığ faile bir ceza tatbik edilmelidir; fakat burada fail, işlediği haksızlıktan dolayı sorumluluğunu hissetmeli ve kusurluluk durumundan ibrası sağlanmalıdır (Cezanın kefaret fonksiyonu) ${ }^{7}$. Öğretide hakim görüş, cezanın böyle bir amacının her zaman olması gerektiğidir ${ }^{8}$. Çünkü kişinin kusurunun temizlenmesi yoluyla topluma kazandırılması, toplumda sağlanması istenen adaletin tesis edilmesine doğrudan katkı sağlayacaktır. Başka bir ifadeyle "rehabilitasyon", "resosyalizasyon" ya da "yeniden topluma entegre etme" olarak da ifade edebileceğimiz bu husus, cezanın infazıyla faile işlediği suçtan dolayı sorumluluğun farkına vardırılması sağlama temeline dayandığından önem arz etmektedir ${ }^{9}$.

Mağdur odaklı yaklaşım ise, “onarıcı”, “tazmin edici”, “uzlaştırıcı”, "tamir edici" kavramlarla ifade edilen ve dünyanın neredeyse yarı coğrafyasında etkinlik kazanan suçun ortaya çıkardığı hasarların ve kayıpların giderilmesi ve tarafların uzlaştırılması esasına dayanan bir yaklaşımdır. Bu anlayış, mağdurun uğradığı zararın sulh yoluyla telafi edilmesiyle toplumsal barış, huzur ve güvenliğin sağlanabileceğini savunmaktadır ${ }^{10}$.

7 Özgenç, s.31. Öğretide cezanın iki önemli amacından bahsedilmektedir. Bunlar cezanın genel önleme ve özel önleme amaçlarıdır. Buna göre, faile cezanın tatbik edilmesiyle "toplumun diğer fertlerine bir gözdă̆ı verilerek" genel önleme amacı; suç işleyenin "yeniden topluma kazandırılmasıyla" özel önleme amacı sağlanmaktadır. Bizim ifade ettiğimiz cezanın kefaret fonksiyonu cezanın bu özel önleme amacına denk gelmektedir. Fakat yine doktrinde cezanın kefaret fonksiyonu hataen bir misilleme olarak tanımlanmaktadır. Yani eden bulmalı, kötülüğe kötülükle karşllık verilmelidir (Soyaslan, s.48). Özgenç’e göre bu durum yanlış tercümeden kaynaklanmaktadır (Özgenç, s.31.).

8 Özgenç, s.31; Koca, Mahmut/Üzülmez, İlhan (2009) Türk Ceza Hukuku Genel Hükümler, 2. Baskı, Ankara, Seçkin Yayıncılık, s.36.

9 Öztürk/Erdem cezanın bu fonksiyonunu "topluma yeniden dönüş için bir köprü" olarak tanımlarken (Öztürk/Erdem, s.30); Soyaslan, bu kurumu, cezanın sosyal savunma teorisiyle açıklamaktadır (Soyaslan, s.51).

Bıçak, s.2. 


\section{ONARICI ADALET}

Onarıcı adalet, bir suç sonucu mağdurun zararının tespiti ve sulh yoluyla tarafların bu zararın tazmininde anlaşması esasına dayanmaktadır ${ }^{11}$. 1974'te bir eğitim programı olarak Kanada'da uygulanmaya başlayan mağdur odaklı bu ceza anlayışı, bilahare Amerika Birleşik Devletleri'nin Indiana eyaletinde uygulanmaya başlamış ve daha sonra ABD'nin diğer eyaletlerinde ve Avrupa'da ${ }^{12}$ onarıcı adalet programları oluşturularak devletlerin ceza sistemlerinde yerini almıştır ${ }^{13}$.

Dünya üzerinde onarıcı adalet anlayışının farklı uygulama şekilleri bulunmaktadır. Bunlar çoğunlukla; uzlaştırma konferansları ${ }^{14}$, barış halkalar1 ${ }^{15}$ ve aile görüşmeleridir ${ }^{16}$.

11 Eriş, Uğur (2018) 'Ceza Muhakemesi Hukukunda Uzlaştırma ve Uzlaştırma Eğitimi' Türkiye Barolar Birliği Dergisi, S:137, s.244; Özbek, Mustafa Serdar (2018) Ceza Muhakemesi Hukukunda Uzlaştırma Eğitim Kitabı, Ankara, Deniz Ofset, s.6.

AB ülkelerinde uzlaştırma programlarının yaygınlaşmasında, Avrupa Konseyi Bakanlar Komitesi'nin 15.09.1999 tarihli R (99) 19 sayılı "Ceza Uyuşmazlıklarında Uzlaştırma” konulu tavsiye kararının etkisi büyüktür (Özbek, Mustafa Serdar (2018) 'Ceza Muhakemesi Kanununda Yapılan Değişiklikler Çerçevesinde Mağdur Fail Uzlaştırmasının Usul Ve Esasları', AÜHFD, S:4, C:56, 2007, s.127.).

Zehr, Howard (2002) 'Perspectives on Restorative Justice' Institute of Peace and Conflict Studies at Conrad Grebel University College, s.1143; Wachtel, Ted (2013) 'Dreaming of a New Reality: How Restorative Practices Reduce Crime and Violence, Improve Relationships and Strengthen Civil Society' Bethlehem, PA: The Piper's Press, s.41.

14 Uzlaştırma konferansları, fail ve mağdurun yanı sıra aile ve arkadaşlarının da katıldığ 1 toplantılardır. Burada, işlenen fiilin zararının nasıl tazmin edileceğine karar verilir. Anlaşma sağlandığında, tazmin şekli ve yolu yazılı olarak kararlaştırılır ve imzalanır. İlgili adli merciler, bu konferansı taraflara alternatif bir seçenek olarak sunmaktadır. (Ayrıntılı bilgi için bkz: O’Connell, Terry, Wachtel, Ben, Wachtel, Ted (1999) The Conferencing Handbook, Pipersville, PA: The Piper's Press. s.11 vd.).

Barış halkaları, insanların hikayelerini anlatmasına ve kendi bakış açılarını sunmalarına izin veren bir uygulamadır. Çoğunlukla bu uygulamalara fail katılmaz, fail hakkında ne yapılması gerektiğine karar verilmektedir. Bu toplantılarda, kişilerin fikirleri ve önerileri kayıt altına alınır, uzlaşma çıkmasa da adli mercilere sunulur (Ayrıntılı bilgi için bkz: Pranis, Kay (2005) The Little Book of Circle Processes. Intercourse, PA: Good Books, s.43 vd.).

161989 yılında Yeni Zellanda'da uygulanmaya başlayan bu görüşme şekli, suçu işleyen çocuğun geniş ailesi ve arkadaşlarıyla birlikte gerçekleştirilen toplantıları ifade etmektedir. 
Onarıcı adalet anlayışı, failin üzerinde yaptırım uygulanarak belirli hukuki sonuçlar doğurmaktan çok mağdurun tatmin edilmesini ön plâna çıkarmaktadır. Yani suç işlenerek bozulan adalet dengesi, sulh yoluyla tarafların anlaştırılması ve zararın giderilmesiyle sağlanmaktadır. Bu anlayış, dört temel ilkeye dayanmaktadır. Bunlar; mağdurun suçtan doğan zararının mümkün mertebe tazmin edilmesi, failin cezai sorumluluğu üstlenmesi, tarafların özgür iradeleriyle uzlaşmak istemesi ve uzlaştırmacının bu ilkeleri tarafsızlıkla ele alıp görevini tamamlamasıdır ${ }^{17}$. Esasen onarıcı adalet failin tekrar topluma kazandırılmasına da hizmet etmektedir. Faile mağdur kadar saygılı davranılarak kanuna uygun hareket etmeleri ve topluma yeniden kazandırılmaları sağlanmaktadır ${ }^{18}$.

\section{TÜRK CEZA HUKUKU SİSTEMIMIZZDE UZLAŞTIRMA KURUMUNUN GELIŞíMI}

Türk ceza hukuku sistemimizde uzlaştırma kurumunu, incelememizin konusunu teşkil eden 7188 sayılı Kanun öncesi ve sonrası olmak üzere iki başlık altında incelemeye çalışacağız.

\section{A. 7188 SAYILI KANUN ÖNCESİ UZLAŞTIRMA KURUMUNUN GELİşìi}

Uzlaştırma kurumu, hukuk sistemimize 5237 sayılı Türk Ceza Kanunu $^{19}, 5271$ sayılı Ceza Muhakemesi Kanunu ${ }^{20}$ ve 5395 sayılı Çocuk

Burada çocuğun sevdikleri akraba veya yakınları sorumluluğu üstlenebilmekte ya da aileye destek vermektedir (Ayrıntılı bilgi için bkz: Doolan, Mike (2003) Restorative Practices and Family Empowerment: Both/ and or either/or? Family Rights Newsletter. London: Family Rights Group, s.57 vd.).

17 Bazemore, Gordon (2005) 'Whomand How Do WeReintegrate? Finding Community in Restorative Justice' Criminology and Public Policy, Vol. 4, s. 131; Baytaz, Abdullah Batuhan (2013) 'Onarıcı Adalet'e Genel Bir Bakış' IÜHFM, Prof. Dr. Füsun SokulluAkıncı'ya Armağan, s. 117.

Arslan, Mualla Buket Soygüt (2010) 'Ceza Hukukunda Mağdurun Korunması ve Onarıcı Adalet Anlayışı’ KHD, S: 2010/1, s. 291 vd.

19 TCK'nın ilk halinde uzlaşma kurumu, 73. maddenin 8. fikrasında şu şekilde düzenlenmişti: 


\section{Koruma Kanunu ${ }^{21}$ ile girmiştir. Bilahare $5560^{22}, 5918^{23}, 6763^{24}$ sayılı Kanunlarla uzlaştırma kurumunun kapsamı genişletilerek CMK’ya alınmıştır.}

"Soruşturulması ve kovuşturulması şikayete bağlı suçlar, uzlaşma

TCK MADDE 73- (8): Suçtan zarar göreni gerçek kişi veya özel hukuk tüzel kişisi olup, soruşturulması ve kovuşturulması şikayete bağlı bulunan suçlarda, failin suçu kabullenmesi ve doğmuş olan zararın tümünü veya büyük bir kısmını ödemesi veya gidermesi koşuluyla mağdur ile fail özgür iradeleri ile uzlaştıklarında ve bu husus Cumhuriyet savcısı veya hakim tarafından saptandığında kamu davası açılmaz veya davanın düşürülmesine karar verilir."

CMK’nın ilk halinde, uzlaşma kurumu 253. maddesinde şu şekilde düzenlenmişti:

“(1) Cumhuriyet savcısı, yapılan soruşturmanın durumuna göre, kanunun uzlaşma yapılabilmesi olană̆ın verdiği hallerde, faili bu Kanunun öngördü̆̆̈̈ usullere göre davet ederek suçtan dolayı sorumluluğunu kabul edip etmediğini sorar.

(2) Fail, suçu ve fiilinden doğmuş olan maddi ve manevi zararın tümünü veya bunun büyük bir kısmını ödemeyi veya zararları gidermeyi kabullendiğinde durum, mağdura veya varsa vekiline veya kanuni temsilcisine bildirilir.

(3) Mağdur, verilmiş olan zararın tümüyle veya büyük bir kısmı itibarıla giderildiğinde özgür iradesi ile uzlaşacağın bildirirse, soruşturma sürdürülmez.

(4) Cumhuriyet savcısı, fail ile mağdur arasında uzlaşma işlemlerini idare etmek, tarafları bir araya getirerek bir sonuca ulaşmalarını sağlamak üzere, fail ve mağdurun bir avukat üzerinde anlaşamadıkları takdirde, bir veya birden fazla avukatın uzlaştırıcı olarak görevlendirilmesini barodan ister.

(5) Uzlaştırıcı, başvurunun yapıldığı tarihten itibaren en geç otuz gün içinde uzlaşmayı sonuçlandırır. Cumhuriyet savcısı bir defaya mahsus olmak üzere bu süreyi otuz gün daha uzatabilir. Uzlaştırma süresince zamanaşımı durur.

(6) Uzlaşma müzakereleri gizli olarak yürütülür. Uzlaşma sırasında ileri sürülen bilgi, belge ve açıklamalar taraflarca izin verilmedikçe daha sonra açıklanamaz. Uzlaştırmanın başarısız olması nedeniyle daha sonra dava açılması halinde uzlaştırma sırasında failin bazı olayları veya suçu ikrar etmiş olması davada aleyhine delil olarak kullanılmaz.

(7) Uzlaştırıcı, yaptı̆̆ı işlemleri ve uzlaşmayı sağlayıcı müdahalelerini belirten bir raporu on gün içinde ilgili Cumhuriyet savcısına sunar.

(8) Zarar, uzlaşmaya uygun olarak giderildiğinde ve uzlaştırma işleminin giderleri, fail tarafından ödendiğinde, kovuşturmaya yer olmadığına karar verilir."

ÇKK’nın ilk halinde uzlaşma kurumu 24. maddesinde şu şekilde düzenlenmişti:

"(1) Suça sürüklenen çocuklarla ilgili olarak uzlaşma, soruşturulması ve kovuşturulması şikâyete bağlı olan veya kasten işlenen ve alt sınırı iki yılı aşmayan hapis veya adli para cezasını gerektiren ya da taksirle işlenen suçlarda uygulanır.

(2) Suç tarihinde onbeş yaşını doldurmayan çocuklar bakımından, birinci fikrada öngörülen hapis cezasının alt sınırı üç yıl olarak uygulanır." 
Ayrıca uzlaştırma müessesesinin uygulanmasına yönelik 2017 tarihli "Ceza Muhakemesinde Uzlaştırma Yönetmeliği”25 çıkarılmış, bilahare 2019 yılında değişiklik yapılmıştır ${ }^{26}$.

\section{B. 7188 SAYILI KANUN'LA UZLAŞTIRMA KURUMUNDA YAPILAN DÜZENLEMELER}

Uzlaştırma müessesesi ile ilgili CMK'da yapılan son düzenleme, 17.10.2019 tarihinde kabul edilen ve 23.10.2019 tarihli Resmi Gazete'de yayımlanarak yürürlüğe giren Ceza Muhakemesi Kanunu Ve Bazı Kanunlarda Değişiklik Yapılmasına Dair Kanun'la olmuştur. Bu Kanunun 26. maddesiyle Ceza Muhakemesi Kanunun uzlaştırmayı düzenleyen 253. maddesinde, süre ile ilgili, uzlaştırmaya tabi suçlar ile ilgili ve uzlaştırma kapsamı ile ilgili üç önemli değişiklik yapılmıştır.

22 06.12.2006 tarihinde kabul edilen ve 19.12.2006 tarihli Resmi Gazete'de yayımlanarak yürürlüğe giren 5560 sayılı Çeşitli Kanunlarda Değişiklik Yapılmasına İlişkin Kanun'la esas itibariyle bir ceza muhakemesi kanunu müessesesi olan uzlaşma tamamıla Ceza Muhakemesi Kanununa alınmıştır. Ayrıca uzlaşmaya tabi suçların sayısı artırılmıştır.

23 26.06.2009 tarihinde kabul edilen 09.07.2009 tarihli Resmi Gazete'de yayımlanarak yürürlüğe giren 5918 sayılı Türk Ceza Kanunu İle Bazı Kanunlarda Değişiklik Yapılmasına Dair Kanun'la Ceza Muhakemesi Kanununun 253. maddesine 3. fikra olarak aşağıdaki metin eklenmiştir: "Uzlaştırma kapsamına giren bir suçun, bu kapsama girmeyen bir başka suçla birlikte işlenmiş olması hâlinde de uzlaşma hükümleri uygulanmaz."

24.11.2016 tarihinde kabul edilen ve 02.12.2016 tarihli Resmi Gazete'de yayımlanarak yürürlüğe giren 6763 sayılı Ceza Muhakemesi Kanunu İle Bazı Kanunlarda Değissiklik Yapılmasına Dair Kanun'la uzlaşma müessesesi uzlaştırma olarak değiştirilmiş ve ceza muhakemesinde uzlaştırma başta olmak üzere alternatif çözümlerin uygulanmasında idari bir organ olarak Adalet Bakanlığı bünyesinde Alternatif Çözümler Daire Başkanlığı kurulmuştur. Yine bu Kanunla, uzlaştırma kapsamına dahil suçların sayısı artırılmış ve mağdurun veya suçtan zarar görenin gerçek veya özel hukuk tüzel kişisi olması koşuluyla, suça sürüklenen çocuklar bakımından ayrıca üst sınırı üç yılı geçmeyen hapis veya adli para cezasını gerektiren suçlarda uzlaştırma kapsamına dahil edilmiştir.

Adalet Bakanlığınca hazırlanan bu yönetmelik, 30145 sayılı ve 05.08.2017 tarihli Resmi Gazete'de yayımlanmıştır.

26 Ceza Muhakemesinde Uzlaştırma Yönetmeliğinde Değişiklik Yapılmasına Dair Yönetmelik, 30395 sayılı (4. mükerrer) ve 31.12.2019 tarihli Resmi Gazete'de yayımlanarak yürürlüğe girmiştir. 


\section{Uzlaştırma Süresi İle İlgili Düzenleme}

Bilindiği üzere CMK, uzlaştırma için 30 günlük bir süre öngörmüş ve bu sürenin bir defaya mahsus 20 gün artırılabileceğini düzenlenmişti. 7188 sayılı Kanunla, uzlaştırmanın ek süresi artırılmış oldu. CMK’nın 253. maddenin 12. fikrasında yer alan "en çok yirmi gün daha” ifadesi, "her defasında yirmi günü geçmemek üzere en fazla iki kez” şeklinde değiştirildi. Böylelikle, otuz günlük uzlaştırma süresine ilaveten iki ayrı yirmi günlük süre ile uzlaştırma süresine ilave edilerek nihai uzlaştırma süresi yetmiş güne çekilmiş oldu. Bu şekilde öğretide, uzlaştırma süresinin artırılmasına yönelik eleştirilerin dikkate alındığını söylemek mümkündür ${ }^{27}$.

Gerçekten de, fail veya mağdurun başka bir yerleşim yerinde bulunması, istinabe yolunun işletilmesi gibi süreci uzatacak durumlarda bu ek sürelerin ihtiyacı ortadadır ${ }^{28}$. Öğretide bir görüşe göre, burada öngörülen süre bir düzenleme süresidir, dolayısıyla sürenin aşılmasında herhangi bir hak kaybı olmayacağı ve bir yaptırımın da uygulanamayacağı ifade edilmektedir ${ }^{29}$. Diğer bir görüşe göre ise, bu süre bir düzenleme süresidir, fakat sürenin aşılması durumunda mesela raporu geç hazırlayan uzlaştırmacı hakkında bir yaptırım uygulanabilecektir ${ }^{30}$. Kanaatimizce buradaki süre, bir hak düşürücü süredir, sürenin aşılması durumunda uzlaştırmanın başarısızlıkla sonuçlandırdığını kabul etmek gerekir ve uzlaştırmacının ilgili yönetmeliğin 49. maddesindeki disiplin sorumluluğu da söz konusu olabilecektir ${ }^{31}$.

27 Erdem, Mustafa Ruhan/Eser, Funda/Özşahinli, Pakize Pelin (2017) 100 Soruda Uzlaştırma, Ankara, Seçkin, s.315-316; Bu sürenin makul olduğuna yönelik düşünceler için bkz: Serdar, s. 178.

Adalet Bakanlığı Ceza İşleri Genel Müdürlüğüne bağlı Alternatif Çözümler Daire Başkanlığı tarafından uzlaştırma kurumunun değerlendirilmesi amacıyla 31 Mart 2018-1 Nisan 2018 tarihlerinde İstanbul'da "Uzlaştırma Çalıştayı" düzenlenmiştir. Bu çalıştayda, $30+30+20+20$ gün olmak üzere 90 günlük bir uzlaştırma süresinin gerekliliğine dikkat çekmişlerdir. Fakat 7188 sayılı Kanunla yapılan değişiklikle, bu süre $70(30+20+20)$ günde kalmıştır. (https://www.youtube.com/watch?v=j12RdEHeqJg, s.e.t. 12.01.2020.). Özbek, s.95 (Adalet Bakanlığı tarafından yayımlanan Uzlaştırma Eğitim Kitabı).

Akbulut, Berrin / Aksan, Murat (2019) Ceza Muhakemesi Hukukunda Uzlaştırma, Ankara, Seçkin, s.222. 
Öğretide bu sürenin varlığına yönelik eleştiriler olsa $\mathrm{da}^{32}$, kanaatimizce bu sürenin varlığı, uzlaştırmacının seri bir şekilde uzlaştırma müzakerelerini tamamlanmasını sağlayacağından varlığı önem arz etmektedir.

\section{Uzlaştırmaya Tabi Suçlar İle İlgili Düzenleme}

CMK'da yer alan uzlaştırma kapsamındaki suçlara, 7188 sayılı Kanunla üç yeni suç tanımı daha eklenmiştir. Bunlar; iş ve çalışma hürriyetinin ihlali (TCK, madde 117, birinci fikra; madde 119, birinci fikra (c) bendi), güveni kötüye kullanma (TCK, madde 155) ve suç eşyasının satın alınması veya kabul edilmesi (TCK, madde 165) suçlarıdır.

Uzlaştırmaya tabi suçların artırılması, kapsamın genişletilmesi ve yeniden düzenlenmesi gereği öğretide en çok dile getirilen eleştirilerin başında gelmektedir $^{33}$. Dolayısıyla yapılan bu kanun değişikliğiyle bu eleştirilerin dikkate alındığı ve uzlaşmadan elde edilen faydanın artırılması istendiğini belirtmek mümkündür ${ }^{34}$. Eklenen bu suç tanımlarıyla ilgili şu açıklamaları yapmak da fayda mülahaza ediyoruz.

engellemiş olur. Şu halde, CMK m.253/12'de ifade edilen sürelerle ilgili amir hüküm karşısında, bunun bir düzenleme süresi olduğunu kabul etmek doğru bir hukuki yaklaşım olmayacaktır, kanaatindeyiz. Benzer yönde görüş için bkz: Ekici Şahin, Meral/Yemenici, Kürşat (2018) '6763 Sayılı Kanunla Yapılan Değişiklikler Işı̆̆ında Ceza Muhakemesi Hukukunda Uzlaştırma’ Erciyes Üniversitesi Hukuk Fakültesi Dergisi, C:13, s.496.

32 Çetintürk, s. 544.

33 Özbek, Veli Özer/Doğan, Koray/Bacaksız, Pınar/Tepe, İlker (2018) Ceza Muhakemesi Hukuku, Ankara, Seçkin, s.832; Erdem/Eser/Özşahinli, s.6; Soygüt Arslan, Mualla Buket (2008) 'Ceza Muhakemesinde Uzlaşma Temel Sorunlar ve Öneriler' Suç ve Ceza Dergisi, S:3, s.83; Şahin, Cumhur (2005) Ceza Muhakemesi Kanunu Gazi Şerhi, Ankara, Seçkin, s.777.

34 Nitekim 7188 sayılı Kanunun uzlaşma kapsamına üç yeni suç tanımı ekleyen 26. maddesinin gerekçesinde şu ifadelere yer verilmiştir: "Düzenlemeyle, uygulamadan gelen talep ve öneriler ile günümüz çağdaş ceza adalet sistemlerinin genel yönelimi dikkate alınarak uzlaştırma kapsamindaki suç listesi genişletilmektedir. Kapsamın genişletilmesiyle, şüphelilerin doğrudan kamu davası ve cezai yaptırımlar yerine, ceza muhakemesinin onarıcı adalete dayanan kurumlarıla karşılaşmaları amaçlanmaktadır. Böylelikle, suçun işlenmesiyle bozulan toplumsal düzen, taraflar arasında sağlanan barış yoluyla yeniden tesis 
a. İş ve çalışma hürriyetinin ihlali (TCK, madde 117, birinci fikra; madde 119, birinci fikra (c) bendi)

TCK'da hürriyete karşı işlenen suçlar bölümünde düzenlenen iş ve çalışma hürriyetinin ihlali suçunun temel şekli(m.117) zaten şikayete bağlı bir suç olarak düzenlenmiştir. Yani bu suç tanımı CMK'da uzlaştırmaya tabi katalog suçlara eklenmeseydi de, şikayete bağlı olmasından bahisle zaten uzlaştırmaya tabi olarak uygulanacaktı. Fakat bu suçun nitelikli hali(m.119(c)), yani birden fazla kişiyle bir kimsenin iş ve çalışma hürriyetinin ihlali re’sen soruşturulduğundan uzlaştırma kapsamında değildi. Şu halde kanun koyucu, bu suçun nitelikli halini uzlaştırma kapsamında dahil etmiş bulunmaktadır. Düzenlemede bir karışıklık olmaması için, temel ve nitelikli halini birlikte zikretmiştir. Fakat bu düzenlemeyle 117. maddenin diğer fikralarında düzenlenen haller (2., 3., ve 4. fikralar) uzlaştırma kapsamı dışında bırakılmıştır.

b. Güveni kötüye kullanma (TCK, madde 155)

Malvarlı̆̆ına karşı işlenen suçlar bölümünde düzenlenen güveni kötüye kullanma suçu, -iş ve çalışma hürriyetinin ihlali suçu gibi- temel şekli (m.155/1) şikayete bağlı ve uzlaşma kapsamında iken; nitelikli hali (m.155/2) re'sen soruşturulduğundan uzlaştırma kapsamında değildi. Yeni düzenlemeyle güveni kötüye kullanma suçu da, aynı şekilde tamamen uzlaşma kapsamına alınmış bulunmaktadır.

c. Suç eşyasının satın alınması veya kabul edilmesi (TCK, madde 165)

Malvarlı̆̆ına karşı işlenen suçlar bölümünde düzenlenen bu suç, TCK 167/2. maddesinde belirtilen kişilerin zararına işlenmesi halinde zaten şikayete tabi ve uzlaşma kapsamındaydı. Kanunun bu düzenlemesiyle, bu suçun temel şekli de (m.165/1), uzlaşma kapsamına dahil oldu. Buradaki hukuki problem, bu suçun mağdurun her zaman doğrudan gösterilememesi ve kiminle uzlaşılacağının belirsiz olmasıdır. Doğrudan mağdurun gösterilemediği

edilmektedir. Ayrıca, uyuşmazlıkların alternatif usuller uygulanarak mağdur odakl bir yaklaşımla giderilmesi, geleneksel muhakeme yoluna nazaran yargı sistemini rahatlatan ekonomik faydalar sağlamaktadır." (<https://www.tbmm.gov.tr/sirasayi/donem27 lyil01/ss105.pdf > s.e.t. 04.02.2020). 
suçlarda mağdur, toplumu oluşturan herkes olduğundan uzlaşma mümkün olmayacaktır. Somut olayda suç eşyasının sahibi ancak bir gerçek kişi veya özel hukuk tüzel kişisine ait ise, uzlaşma mümkün olacaktır. Fakat eşyanın asıl sahibi tespit edilemiyorsa uzlaştırmanın yapılamayacağı kanaatindeyiz.

Kanaatimizce her kanun değişikliğiyle uzlaştırmaya tabi suçlara birkaç suç tanımı eklemek yerine, daha kapsayıcı ve genel bir hüküm konulması isabetli olacaktır. Mesela, "ağır ceza mahkemesi görevine giren suçlar hariç olmak üzere her suç için uzlaştırma mümkündür” şeklinde bir düzenleme yapılması yerinde olacağı kanaatindeyiz.

\section{Uzlaştırma Kapsamı İle İlgili Düzenleme}

Yine 7188 sayılı Kanunla CMK'nın 253. maddesinin 3. fikrası yeniden düzenlenmiş; uzlaştırma kapsamına giren bir suçun bu kapsama girmeyen başka bir suçla işlenmesi halinde mağdurun aynı olması halinde uzlaştırmanın yapılamayacağı ifade edilmiştir.

$\mathrm{Bu}$ düzenlemeden önce madde metninde, uzlaştırma kapsamında giren bir suçun, bu kapsama girmeyen bir başka suçla birlikte işlenmesi halinde, uzlaştırma yoluna gidilemeyeceği ifade ediliyordu. Mesela, konuta gündüz vakti giren bir hırsız, ev sahibini silahla yaralasa ve bir komşusunun da paralarını çalsa, önceki düzenlemeye göre bu fiillerin hiçbirisi uzlaştırma kapsamına alınmıyordu. Çünkü bu fiillerin içerisinde silahla yaralama uzlaştırma kapsamı dışında olduğundan; diğer fiiller, hırsızlık ve konut dokunulmazlığı ihlal suçları uzlaştırma kapsamında olsa da uzlaştırma yapılmıyordu. CMK 253/3'le yapılan değişiklikle, mağdurları farklı ise uzlaştırma kapsamına giren bir suç, girmeyen bir başka suçla işlense de artık uzlaştırma yapılabilecektir. Verdiğimiz örnekte parası çalınan komşu ile fail arasında uzlaştırmanın yapılması mümkün hale gelmiştir. Fakat konut dokunulmazlığı ihlal edilen ve silahla yaralanan ev sahibi için uzlaştırma yapılamayacaktır. Çünkü bu suçların mağduru aynıdır. Konut dokunulmazlığı ihlal suçu uzlaştırma kapsamında olsa da, silahla yaralama uzlaştırma kapsamı dışındadır. 
Uzlaştırma kurumundan beklenen faydalar dikkate alındığında, uzlaştırma kurumunun kapsamının daha da genişletilmesi gerektiğini tekrar ifade etmek istiyoruz. Dolayısıyla uzlaştırma kapsamında giren bir suç, uzlaştırma kapsamında girmeyen bir suçla birlikte işlenirse, ağır ceza mahkemesinin alanına giren bir suç değilse, tamamen uzlaştırma kapsamına alınmalıdır, düşüncesindeyiz ${ }^{35}$.

\section{Uzlaştırma Kurumuna Yöneltilen Mevcut Eleştiriler}

7188 sayılı Kanunla getirilen yeniliklere işaret ederken uzlaştırma süresi, uzlaştırmaya tabi suçlar ve uzlaştırma kapsamına yönelik eleştiri ve önerilerimizi ifade etmiş olduk. Bu konuların dışında uzlaştırma kurumuna yönelik öğretide eleștiri konusu edilen önemli hususları incelemek istiyoruz.

a. Şüpheli/sanığın Birden Fazla Uzlaştırmadan Yararlanmasına Engel Olunmalıdır.

Taraflar arasında sağlanan sulh marifetiyle anlaşmazlı̆̆ tamamen çözme imkanını getiren uzlaşma, toplumsal adaletin sağlanması bakımından önemli bir enstrüman durumundadır. Dolayısıyla bu enstrümanın kötüye kullanılmaması, doğru sonuç alınması için belirli tedbirlerin alınması gerekir. Her defasında konut dokunulmazlığını ihlal, hırsızlık suçundan uzlaştırma masasına gelen bir fail için, uzlaştırma bir ceza yaptırımına karşı can simidi işlevi görmemelidir. Kanaatimizce en azından aynı suçtan birden fazla uzlaştırma mümkün olmamalıdır. Başka bir ifadeyle, aynı fail için aynı tür bir suçtan bir kez uzlaştırma mümkün olmalı, ikincisi için bir ceza yaptırımı uygulanmalıdır ${ }^{36}$.

b. Uzlaştırma Hem Soruşturma Hem Kovuşturma Aşamasında Denenmesi Gereken Bir Yol Olmalıdır.

2013 tarihli Yargıtay Ceza Genel Kurulu kararı, uzlaştırmanın asıl olarak soruşturma aşamasında uygulanması gerektiğine karar vermiştir ${ }^{37}$.

35 Benzer görüş için bkz: Çetintürk, Ekrem (2009) Ceza Adalet Sisteminde Uzlaştırma, Ankara, Seçkin Yayıncılık, s.485.

36 Erdem/Eser/Özşahinli, s.7.

37 Y., CGK, 22.01.2013, E: 2012/6-1142, K: 2013/17. 
Mevzuatımız ise, soruşturma ve kovuşturma evresinde uzlaştırma hususunu ayrı ayrı incelese de esas olarak soruşturma aşamasında uzlaştırma yapılmasını benimsemektedir. Mesela, soruşturma evresinde uzlaştırmacının teklifi sonuçsuz kalırsa, taraflar özgür iradeleriyle Cumhuriyet savcısına her zaman uzlaştıklarını beyan edebilirler (CMK, m.253/16; Uzlaştırma Yönetmeliği, m.17/2). Artık bu durumda cumhuriyet savcısı tarafların mutabık kaldığı hukuka uygun bir edim belirleyip uzlaştırmayı gerçekleştirecektir. Fakat kovuşturma evresinde, belirli durumlarda uzlaştırma yapabileceği uzlaştırma yönetmeliğinde ifade edilmiştir. Buna göre yönetmeliğin 26. maddesinin 1 . fikrasında şu düzenleme yapılmıştır: "Kovuşturma evresinde uzlaştırmanın uygulanabileceği hallerde, yapılan uzlaşma teklifinin reddedilmesine rağmen hüküm verilinceye kadar sanık ile mağdur, katılan veya suçtan zarar görenin aralarında uzlaşmaları halinde; taraflarca niteliğine uygun düsstüğ̈̈ ölçüde Ek3'te yer alan Uzlaştırma Raporu Örneği'ne uygun bir uzlaşma belgesi düzenlenir ve mahkemeye sunulursa, hakim bu belgeyi 25 inci maddenin dördüncü ve beşinci fikralarında belirtilen kıstaslara göre inceler ve değerlendirir." Yani uzlaştırmacı dışında da, kovuşturma mercii uzlaştırma yapabilecektir. Fakat bu haller, madde metninin başında ifade edildiği üzere, "kovuşturma evresinde uzlaştırmanın uygulanabileceği haller"dir. Bu haller ise, yine yönetmeliğin 22. maddesinde tadadi olarak sayılmıştır. Bu haller;

a) Kovuşturma konusu suçun hukuki niteliğinin değişmesi nedeniyle uzlaşma kapsamında olduğunun anlaşılması,

b) Soruşturma evresinde uzlaşma teklifinde bulunulması gerektiğinin ilk olarak kovuşturma evresinde anlaşılması,

c) Cumhuriyet savcısı tarafından iddianame düzenlenmeksizin, iddianame yerine geçen belge ile doğrudan mahkeme önüne gelen uzlaşmaya tabi bir suçun varlı̆̆

d) Kovuşturma evresinde kanun değişikliği nedeniyle suçun uzlaşma kapsamına girmesidir (Uzlaştırma Yönetmeliği, m.22/1).

Şu halde soruşturma evresinde uzlaştırmacı tarafindan uzlaştırma yapılamazsa, iddianamenin düzenlenmesine kadar taraflar Cumhuriyet savcısı marifetiyle de uzlaşabilecekken; kovuşturma evresinde ise belirli durumlarda 
mahkeme tarafları uzlaştırabilecektir. Mesela, soruşturma evresinde basit yaralama fiilinden uzlaştırmacının teklifini reddetmişler, kovuşturma evresinde uzlaşmaya karar verseler, yönetmeliğe göre bu mümkün olmayacaktır. Kanaatimizce bu durum uzlaştırma müessesesinin ruhuna düzenlenme amacına uygun düşmemektedir. Kanunun açıkça yasaklamadığ kovuşturma evresinde uzlaştırma kurumunu daraltacak düzenlemeleri yönetmelik yapmamalıdır. Kanaatimizce Yönetmeliğin 22. maddesine kovuşturma evresinde uzlaştırmanın uygulanabileceği hallere "soruşturma evresinde uzlaştırmacının başarısız olması” ibaresi eklenmelidir. Böylelikle uzlaştırma kurumu, hem soruşturma hem kovuşturma aşamasında denenmesi gereken bir yol olmalıdır. Yani soruşturma evresinde uzlaştırma teklifi başarısız olsa da, bir defaya mahsus olmak üzere kovuşturma evresinde de uzlaşma teklifi yapılmalıdır ${ }^{38}$.

c. Kamu Tüzel Kişilerinin de Uzlaştırma Kurumundan İstifade Etmesi Gerekir.

CMK’nın 253. maddesinde, mağdurun kamu hukuku tüzel kişisi olması hâlinde uzlaştırmaya başvurulamayacağ Başka bir ifadeyle, kanun koyucunun izlemiş olduğu ceza siyaseti gereği bir kamu hukuku tüzel kişisi suçtan zarar görse de, uzlaştırmanın tarafı olamamaktadır. Oysaki kamu tüzel kişilerine karşı işlenen suçlarda da, mesela kamu malına zarar verme suçu(TCK, m.152) gibi uzlaştırmadan yararlanılması mümkün olması gerektiği öğretide ifade edilmiştir $\mathrm{ki}^{39}{ }^{39} \mathrm{bu}$ düşünceye katılmaktayız. Şu halde kamu hukuku tüzel kişileri 'fail' veya 'mağdur' olması mümkün gözükmese de, pekala 'suçtan zarar gören' sıfatına sahip olması mümkündür ve uzlaştırmanın tarafı olabilmelidir.

$\mathrm{Bu}$ durum, mağduru doğrudan gösterilemeyen suçlarda devletin yani kamu tüzel kişisinin mağdur olduğu ifade edilip bu suçlarda da uzlaştırmanın

Erdem/Eser/Özşahinli, s.8.

39 Serdar, s.156; Güngör, Mümin (2019) Ceza Yargılamasında Uzlaştırma, Ankara, Adalet, s.196. 
mümkün olamayacağı şeklinde anlaşılmamalıdır ${ }^{40}$. Yani mağduru doğrudan belli olmayan suçlarda pekala suçtan zarar gören bir gerçek kişi olabilir ve uzlaştırma kurumunun tarafı olabilir. Mesela, 16-17 yaşında evlenen bir bayanın henüz Türk ceza kanunu anlamında çocukken gebeliğini kendi imkanlarıyla mesela, kürtaj hapı içerek sonlandırması halinde ve eşinin de bundan haberdar olmadığını farz edelim. Burada söz konusu fiil TCK m.100 anlamında çocuk düşürmedir ve bu suç, şikayete bağlı değildir ve uzlaştırmaya tabi katalog suçlar arasında da sayılmamaktadır. Başka bir ifadeyle çocuk düşürme suçu, kural olarak uzlaştırma kapsamı dışındadır. Olayımızda bilahare eşin(kocanın) bu durumdan haberdar olup boşanma davası açtığı ihtimalinde ayrıca çocuğu düşüren eşinden şikayetçi olduğunu düşünelim. Burada suçun mağduru, doğrudan gösterilemediğinden toplumu oluşturan her gerçek kişidir(geniş anlamda mağdur kavramı). Ayrıca bu suçun, suçtan zarar göreni de mevcuttur; o da neslini devam ettirme hakkından mahrum kalan eşidir. Fail ise gebeliğini sonlandıran bayandır. Fail, TCK anlamında çocuk olduğu için, üst sınırı 3 yılın altında olan çocuk düşürme suçu da mağduru toplum da olsa- uzlaştırmaya pekala tabi olmalıdır.

d. Cinsel Suçlarda Uzlaştırmanın Yolu Kapatılmamalıdır.

CMK'da 5560 sayılı Kanunla değişiklik yapılmadan önce, cinsel dokunulmazlığa karşı işlenen suçlarda uzlaştırma mümkünken; 5560 sayılı Kanunla yapılan değişiklikle, bu suçlarda uzlaştırma engellenmiştir. Oysaki bu suçlarda da uzlaştırmanın mümkün olması gerektiği öğretide dile getirilmiştir $\mathrm{ki}^{41}$ bu düşünceye katılmaktayız. Burada mağdurun uzlaşmak istemesi ve kendi menfaatine uygun bulması durumunda pekala uzlaştırma masasına oturabilmelidir. Esasen cinsel dokunulmazlığa karşı işlenen suçlarda uzlaştırma yolunun kapatılması, mağdura yaşadığı acı tecrübeyi ceza muhakemesi sürecinde tekrar yaşatabilmekte ve psikolojik yönden daha fazla zarar görebilmektedir. Pekala mağdur, gizli olan uzlaştırma süreci sonunda,

40 Akbulut/Aksan, s.88; Özbek, s.57. Devletin bir suçun mağduru olduğu görüşü klasik ceza hukuku anlayışının bir ürünüdür, yeni ceza hukuku sistemimizde sadece gerçek kişiler, suçun mağduru veya faili olabilirler (Ayrıntılı açlklama için bkz: Özgenç, s. 214 vd).

41

Serdar, s.157; karşı görüş için bkz: Güngör, s.156; Erdem/Eser/Özşahinli, s.40. 
lehine yapacağ 1 bir uzlaşma anlaşmasıyla, failin cezalandırılmasına nazaran daha fazla fayda elde edebilmesi mümkündür.

\section{SONUÇ}

Uzlaştırma, mağdur ile faili tarafsız bir üçüncü kişinin yönetiminde bir araya getirerek karşılıklı olarak birbirlerini anlamaya çalışmalarına imkan sağlamaktadır. Bu sayede fail, ceza tehdidinden kurtulma ve hatalarını telafi etme, mağdur ise suçtan dolayı oluşan maddi ve manevi zararlarını giderme fırsatı yakalamaktadır. Uzlaştırmanın, yargılama sürecinden daha hızlı şekilde uyuşmazlığın çözüme kavuşturulması ve yargı organlarının iş yükünü azaltması bakımından ceza adalet sistemine ve suçla bozulan toplumsal düzen ve barışın yeniden tesis edilmesi bakımından topluma yönelik faydaları da bulunmaktadir.

Şu halde fail ve mağduru uzlaşmaya götürecek önemli hususlar varken, bu müessese olabildiğince genişletilmelidir. Çünkü toplumsal barışın sağlanmasına hizmet edecek bu kurum, sayılamayacak faydayı beraberinde getirmektedir. Bu mülahazalarla, uzlaştırmaya tabi suçları belirlerken şikayete tabi suçlara ek olarak sayma yöntemi yerine "suçun ağırlığı ve cezanın miktarı" gibi objektif bir ölçütün benimsenmesi daha yerinde olacaktır. İfade ettiğimiz üzere kanaatimizce, "ağır ceza mahkemesi görevine giren suçlar hariç olmak üzere her suç için uzlaştırma” mümkün olmalıdır.

Esasen şikayete bağlı suçlar dışında bazı suçların da sayılarak uzlaştırma kapsamında alınmasında, bazı sakıncalar da söz konusu olabilmektedir. Yani sayma sisteminde suçların haksızlık muhtevasının ağırlığını tespitte zorluklar çıkabilmektedir. Buna bir örnek verelim. Mesela, TCK m. 86/1-2'de düzenlenen kasten yaralama fiili uzlaştırmaya tabidir, fakat m.86/3(a)'da düzenlenen yakın akrabaya karşı işlenmesi durumunda, bu fiil uzlaştırma kapsamı dışındadır. Oysa ki, yakın akrabalar arasında yeniden barışın ve huzurun tesisi ve aile düzeninin sağlanması önem arz eder ve daha kolay olabilmektedir. $\mathrm{Bu}$ yönüyle bu fiilleri uzlaştırma kapsamına alarak aile düzenin yeniden tesisine imkan sağlamak gerekir. Bir başka husus ise, yakın akrabalara karşı yaralama fiillerinde, şikayetten vazgeçilse de, bu suç re'sen 
soruşturulduğundan kamu davası açılmakta ve ceza muhakemesi süreci tamamlanmaktadır. Şu halde bu suçun(TCK, m.86/3(a)) uzlaştırma kapsamına alınması aile kurumu için de önem arz etmektedir. Özetle uzlaştırmaya tabi tek tek suçların sayılması yerine kapsayıcı genel bir hüküm konulması, ifade ettiğimiz üzere daha yerinde olacaktır.

Keza cinsel suçlarda uzlaştırma imkanının getirilmesi, kamu hukuku tüzel kişilerinin de uzlaştırma masasına gelebilmesi ve aynı failin işlediği aynı suçlardan sadece bir kez uzlaştırmadan faydalanabilmesi savunduğumuz görüşlerdendir. $\mathrm{Bu}$ görüşlerimizin de temelinde, uzlaşma müessesesinin getirdiği öncelikli fayda olan toplumsal mutabakat yer almaktadır. Başka bir ifadeyle uzlaştırma müessesesinin kapsamı olabildiğince genişlemeli ki, toplumsal mutabakat daha fazla vakıada sağlanmış olsun. 


\section{KAYNAKÇA}

Akbulut, Berrin / Aksan, Murat (2019) Ceza Muhakemesi Hukukunda Uzlaştırma, Ankara, Seçkin.

Arslan, Mualla Buket Soygüt (2010) 'Ceza Hukukunda Mağdurun Korunması ve Onarıcı Adalet Anlayışı’ KHD, S:2010/1, s. 283-310.

Baytaz, Abdullah Batuhan (2013) 'Onarıcı Adalet'e Genel Bir Bakış' IÜHFM, Prof. Dr. Füsun Sokullu-Akıncı'ya Armağan, s. 117-129.

Bazemore, Gordon (2005) 'Whomand How Do WeReintegrate? Finding Community in Restorative Justice' Criminology and Public Policy C:4, S:1, s. 131-148.

Bıçak, Vahit (2018) 'Onarıcı Adalet Yaklaşımıyla Ceza Adalet Sisteminin Yeniden İnşası', A̧urası, Ankara, (https://www.bicakhukuk.com/wp-content/uploads/2018/01/VahitB\%C4\%B1\%C3\%A7ak-2018-Adalet-\%C5\%9Euras\%C4\%B1Tebli\%C4\%9F.pdf, s.e.t:29.11.2019).

Çetin, Soner H. (2009) 'Ceza Muhakemesi Kanunda Uzlaşma' Türkiye Barolar Birliği Dergisi, S:82, s.1-33.

Çetintürk, Ekrem (2009) Ceza Adalet Sisteminde Uzlaştırma, Ankara, Seçkin Yayıncilik.

Doolan, Mike (2003) Restorative Practices and Family Empowerment: Both/ and or either/or? Family Rights Newsletter. London: Family Rights Group.

Güngör, Mümin (2019) Ceza Yargılamasında Uzlaştırma, Ankara, Adalet.

Ekici Şahin, Meral/Yemenici, Kürşat (2018) '6763 Sayılı Kanunla Yapılan Değişiklikler Işı̆̆ında Ceza Muhakemesi Hukukunda Uzlaştırma’ Erciyes Üniversitesi Hukuk Fakültesi Dergisi, C:13, s.445-546.

Erdem, Mustafa Ruhan/Eser, Funda/Özşahinli, Pakize Pelin (2017) 100 Soruda Uzlaştırma, Ankara, Seçkin.

Eriş, Uğur (2018) 'Ceza Muhakemesi Hukukunda Uzlaştırma ve Uzlaştırma Eğitimi’ Türkiye Barolar Birliği Dergisi, S:137, s.241-271.

Koca, Mahmut/Üzüllmez, İlhan (2009) Türk Ceza Hukuku Genel Hükümler, 2. Baskı, Ankara, Seçkin Yayıncılık. 
O'Connell, Terry, Wachtel, Ben, Wachtel, Ted (1999) The Conferencing Handbook, Pipersville, PA: The Piper's Press.

Özbek, Mustafa Serdar (2007) 'Ceza Muhakemesi Kanununda Yapilan Değişiklikler Çerçevesinde Mağdur Fail Uzlaştırmasının Usul ve Esasları' AÜHFD, S:4, C:56, s.123-205.

Özbek, Mustafa Serdar (2018) Ceza Muhakemesi Hukukunda Uzlaştırma Eğitim Kitabı, Ankara, Deniz Ofset.

Özbek, Veli Özer/Doğan, Koray/Bacaksız, Pınar/Tepe, İlker (2018) Ceza Muhakemesi Hukuku, Ankara, Seçkin.

Özgenç, İzzet (2015) Türk Ceza Hukuku Genel Hükümler, 11. Bası, Ankara, Seçkin.

Öztürk, Bahri/Erdem, Mustafa Ruhan (2005) Uygulamalı Ceza Hukuku ve Güvenlik Tedbirleri Hukuku, 13. Baskı, Ankara, Seçkin.

Pranis, Kay (2005) The Little Book of Circle Processes. Intercourse, PA: Good Books.

Soyaslan, Doğan (2017) Ceza Hukuku Genel Hükümler, Ankara, Yetkin.

Soygüt Arslan, Mualla Buket (2008) 'Ceza Muhakemesinde Uzlaşma Temel Sorunlar ve Öneriler’ Suç ve Ceza Dergisi, S:3, s.81-89.

Şahin, Cumhur (2005) Ceza Muhakemesi Kanunu Gazi Şerhi, Ankara, Seçkin.

Wachtel, Ted (2013) 'Dreaming of a New Reality: How Restorative Practices Reduce Crime and Violence, Improve Relationships and Strengthen Civil Society' Bethlehem, PA: The Piper's Press.

Wachtel, Ted (2016) 'Defining Restorative' IIRP International Institute.

Yerdelen, Erdal/Özbek, Mustafa Serdar/Altuntaş, Şeyda/Boz, Burak/Erdem, Dilek Özge/Yılmaz, Berna Ayşen (2018) Ceza Muhakemesi Hukukunda Uzlaştırma, Ankara, Adalet.

Zehr, Howard (2002) 'Perspectives on Restorative Justice' Institute of Peace and Conflict Studies at Conrad Grebel University College.

$<$ https://www.tbmm.gov.tr/sirasayi/donem27/yil01/ss105.pdf> s.e.t. 04.02.2020. 